\title{
科学技術の国際交流について
}

\section{山中千代 衛*}

\section{Chiyoe YAMANAKA*}

科学技術は人類共通の財産であり，これが国 際的に十分活用され，人類が直面している諸問 題の解決に役立つことが強く望まれるのである。

科学にはもともと国境はなく, 技術も相互互 恵の原則の下，広く交流が行われるべきもので ある。しかし現実にはこの豊かなるべき智恵が 軍事応用と結びついて秘婼されたり, 制限され たりしている事例が散見される。

資源は有限であり，地球で人類の成長には自 ら限界があるというローマクラブの提言にまつ までもなく，人類はもっと連帯して能力をつく し，よりよい明日が期待できるようにしなけれ ばならない。

わが国は東洋の一画に位置し, 欧米諸国と地 理的に隔絶しているため, 過去において国際交 流ではかなりのハンディキャップを荷ってきた。 それにもかかわらず戦後零から出発し, 持前の 勤勉さと生張面さにより世界の先進諸国に追つ くとともに技術立国の望みを果しつつある。

しかし，わが国の立場は今や曲り角にきてお り，国内的にも国際的にも従来のパターンで対 処することは困難になっている。過去に成功を 収めた技術導入政策とは全く別の次元で科学技 術の振興に有力な手段として国際交流を認識す る必要がある。国際交流の重視は研究への直接 的施策を補完するものであって，有効適切に運 用すればその成果は計り知れないものがある。

まず第一に外国から学ぶべきことが無くなり つつある現在, 海外からの論文, 出版物による 情報はあまり価值がなく, 直接国際的な討論に より必要な展開をはかる時代になってきたので
ある。まさに科学技術の第一線において諸外国 と互に啓発しあいつつ進歩を求めることになつ たのだ。この目的のためには積極的に意識して ワークショップ形式の会合をしばしば国の内外 で開催することなどの施策が必要である。

第二には欧米の科学コミュニティでは常識で ある外国人研究者の雇用を奨励すべきである。 これは海外より第一級の学者, 研究者を招聘し て教えを請うというょうな従来のパターンでは なく,わが国の研究組織の中に若干の外国人を 組込むことである。わが国では欧米と異って， このような場合言語の障壁が立ちはだかる心配 があるので受入れ側は十分の対策を用意するこ とが肝要であろう。

第三は国際的共同研究の組織化である。この 試みは研究の二重投資をさけることや，広い正面 を分担して開拓研究するのに適している。しか しこの方式の採用に当ってはギブ・アンド・テ イクの原則が明白に作用することを銘記すべき である。過去30年, や、もすれば研究の成果の みを導入しようとしたわが国の弊風を清算し， 長期的に収支をバランスさせる抜本的な計画を 持つことが大切である。模索的な段階から積極 的に対応し，自主的な技術の開発を推進し，そ れを背景にして国際的に相補う有効な協力を行 う必要がある。

従来，しばしば国際交流と国際親善とを同義 的に理解する趣があったが, 国際交流は相互主 義の原則にもとづく一種の国際競争と考えられ るべきである。またその覚悟なくしてはわが国 の地位は国際的に危うしと言うべきである。 